\title{
The Immigration and Refugee Board
}

The Immigration and Refugee Board (IRB) was established as part of the amendments to the Immigration Act when Bill C-55 was given Royal assent on July 21, 1988. The Board is an indepen- dent administrative tribunal that assumes the functions of the former Refugee Status Advisory Committee and the Immigration Appeal Board.

The IRB, the largest administrative

\begin{tabular}{|cc|}
\hline \multicolumn{2}{|c|}{ IMMIGRATION AND REFUGEE BOARD } \\
(IRB) \\
CHAIRMAN \\
Convention Refugee \\
$\begin{array}{c}\text { Gordon Fairweather } \\
\text { Determination Division }\end{array}$ & $\begin{array}{c}\text { Immigration Appeal } \\
\text { (CRDD) }\end{array}$ \\
Deputy Chairman & (IAD) \\
Drasko Bubalo & Deputy Chairman \\
CRDD & Nurjehan N. Mawani \\
- Stanley B. Knight & IAD \\
Vancouver Region & Assistant Deputy Chairmen \\
- Elizabeth Bryant & Andrew Z. Wlodyka \\
Prairie Region (Calgary) & Vancouver Region \\
- Dorothy Davey & Lila Goodspeed \\
- Anna Ker & Prairie Region \\
Toronto Region & (Winnipeg) \\
- Colette Savard & Kathi I. Arkin \\
Montreal Region & Toronto Region \\
& - Joseph S. Blumer \\
\hline & Montreal Region \\
\hline
\end{tabular}

tribunal in Canada, has two distinct divisions, the Convention Refugee Determination Division (CRDD) and the Immigration Appeal Division (IAD). These are linked administratively but remain independent of each other in their decision-making. The CRDD has sole responsibility from the outset for refugec determination. The IAD handles appeals by sponsors of family members and appeals by persons ordered removed from Canada. Refugee claimants may not appeal to the IAD.

Headed by Gord on Fairweather, who is backed by two Deputy Chairmen and ten Assistant Deputy Chairmen, the IRB will have up to 65 full-time members in its Refugee Division and up to 30 permanent members in its Appeal Division. Refugee Division members are ex officio members of the Appeal Division, but the reverse is not true.

The appointecs will have to undergo intensive training and briefings during a three-week residence programme before starting work on November 15.

The IRB will be supported by a documentation centre with information on human rights, country of origin conditions and on refugee law. The centre will also establish an advisory body of refugee experts.

"The IRB must also be an independent organization. Our legislated mandate permits no political influence of any kind on our decision-making. Indeed, the fact that I, as Chairman of the Board, am here making this announcement today underscores the commitment of the Government to the independece of the IRB."

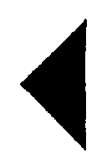

Gordon Fairweather, news release, August 30, 1988

"The new assistant deputy chairman for the Montreal region is Gisèle Morgan, former associate national director of the Conservative Party. Her husband, Keith, is Prime Minister Brian Mulroney's riding assistant. Her son, Richard, is Mr. Mulroney's executive assistant. ...

The second Quebec appointment is Colette Savard of Montreal, a lawyer who knows Mr. Mulroney from his Baie-Comeau days and has been active with PC women's groups in Quebec....

The third Montreal appointment is Joseph Blumer, a former director of the Conservative Party's Quebec wing...."

Richard Cleroux, The Globe and Mail, September 2, 1988 